\title{
Different action of alkali/alkaline earth metal chlorides on cellulose pyrolysis
}

\section{$\operatorname{AUTHOR}(\mathrm{S})$ :}

Shimada, Naoki; Kawamoto, Haruo; Saka, Shiro

\section{CITATION:}

Shimada, Naoki ... [et al]. Different action of alkali/alkaline earth metal chlorides on cellulose pyrolysis. Journal of Analytical and Applied Pyrolysis 2008, 81(1): 80-87

\section{ISSUE DATE:}

2008-01

URL:

http://hdl.handle.net/2433/240764

\section{RIGHT:}

(c) 2007. This manuscript version is made available under the CC-BY-NC-ND 4.0 license

http://creativecommons.org/licenses/by-nc-nd/4.0/; The full-text file will be made open to the public on 1 January 2010 in accordance with publisher's 'Terms and Conditions for Self-Archiving'.; この論文は出版社版でありません。引用の際 には出版社版をご確認ご利用ください。; This is not the published version. Please cite only the published version. 
Title:

\title{
Different action of alkali / alkaline earth metal chlorides
}

\section{on cellulose pyrolysis}

Authors:

\author{
Naoki Shimada, H. Kawamoto*, S. Saka \\ * Corresponding author: Tal/ Fax: +81-75-753-4737 \\ Email address: kawamoto@energy.kyoto-u.ac.jp (H. Kawamoto)
}

Full postal address of the person to whom proofs are to be sent:

Graduate School of Energy Science, Kyoto University

Yoshida-honmachi, Sakyo-ku, Kyoto 606-8501, Japan

Number of pages: 12

Number of Tables: 1

Number of Figures: 10 


\section{ABSTRACT}

The influence of alkali metal chlorides $(\mathrm{NaCl}, \mathrm{KCl})$ and alkaline earth metal chlorides $\left(\mathrm{MgCl}_{2}, \mathrm{CaCl}_{2}\right)$ on cellulose pyrolysis was studied with thermal analysis and isothermal pyrolysis in $\mathrm{N}_{2}$ at $150-400^{\circ} \mathrm{C}$. Alkali and alkaline earth metal chlorides affected the cellulose pyrolysis in different way. Although alkali metal chlorides did not change the weight loss temperature of bulk cellulose (main part of cellulose) so much, alkaline earth metal chlorides substantially reduced the temperature. Furthermore, the influence of alkaline earth metal chlorides on the weight loss behavior $\left(<400^{\circ} \mathrm{C}\right)$ was very dependent on the amount of loading bellow $0.30 \mathrm{~mol} / \mathrm{mol}$ of the glucose-unit of cellulose, while the influences of the alkali metal chlorides were almost independent of the amount. Both metal chlorides significantly changes the low MW product composition even at a very low level of addition.

Keywords: Cellulose, pyrolysis, influence of metal chloride, alkali metal, alkaline earth metal, $\mathrm{NaCl}, \mathrm{KCl}, \mathrm{MgCl}_{2}, \mathrm{CaCl}_{2}$, thermogravimetry, differential thermal analysis 


\section{INTRODUCTION}

It is well-known that inorganic matter affects the cellulose pyrolysis [1-15]. Since pyrolysis is the fundamental principle of various thermochemical conversion processes of cellulosic biomass, the details of these influences are important for understanding and improve these processes. Demineralized [1-7], cation-exchanged [6-8] and impregnated [4, 9-13] wood or cellulose samples have been used to study the influence. Many studies also have focused on the improvement of the antiflammability of wood and cellulose by impregnating the inorganic matter such as boric acid and phosphate [14].

As for the neutral salts, many studies have been conducted with alkali metal halides [4, 9-13, 15] such as $\mathrm{NaCl}$ and $\mathrm{KCl}$, and the decreasing yield of levoglucosan (1,6-anhydro- $\beta$-D-glucopyranoside), increasing yields of char, carbon monoxide and water and reducing the pyrolysis-starting temperature have been reported as their influence on cellulose pyrolysis. On the other hand, there are several papers $[2,5,16$, 17], which report some conflicting influences of alkaline earth metal halides.

Várhegyi et al. [11] reported that the influence of magnesium chloride $(0.01 \mathrm{~mol} /$ mol of glucose-unit) on the weight loss behavior of cellulose is small in thermogravimetric (TG) analysis. Müller-Hagedorn et al. [5] also reported that the DTG peak $\left(\sim 370^{\circ} \mathrm{C}\right)$ corresponding to the cellulose decomposition was not affected so much by impregnation of $\mathrm{CaCl}_{2}(0.5 \mathrm{wt} \%)$ to hornbeam wood. Contrary to these results, Kawamoto et al. [16] have reported that alkaline earth metal chlorides $\left(\mathrm{MgCl}_{2}\right.$, $\mathrm{CaCl}_{2}$ ) substantially increased the char yield in cellulose pyrolysis under $\mathrm{N}_{2}$ at $400^{\circ} \mathrm{C}$ with decreasing yield of levoglucosan. They also reported that these effects were even much greater than those of alkali metal chlorides $(\mathrm{NaCl}, \mathrm{KCl})$. Tsuchiya and Sumi [9] reported that $1 \%$ addition of $\mathrm{CaCl}_{2}$ to cellulose reduced the levoglucosan yield from $10.1 \%$ to $0.1 \%$ at $320^{\circ} \mathrm{C}$.

In this article, influences of alkaline earth metal chlorides on cellulose pyrolysis, which were studied with thermal analysis and isothermal pyrolysis, are presented as compared with those of alkali metal chlorides.

\section{EXPERIMENTAL}




\subsection{Materials}

Filter paper [Kiriyama No. 704, cotton, $\alpha$-cellulose content [17]: >99\%, number average of degree of polymerization (DP): 700 (GPC analysis as phenyl carbamate derivative, polystyrene standard), crystallinity: 82\% (X-ray diffraction), inorganic impurity [17]: K (<1ppm), Na (<10ppm), Ca (17ppm), Mg (1ppm), Al (<2ppm), Mn $(<0.5 \mathrm{ppm}), \mathrm{Zn}(<1 \mathrm{ppm}), \mathrm{Fe}(<5 \mathrm{ppm}), \mathrm{Cu}(<1 \mathrm{ppm})]$ was used as a cellulose sample after drying at $105^{\circ} \mathrm{C}$ for $24 \mathrm{~h}$. Aqueous solutions $(125 \mu \mathrm{l})$ of $\mathrm{NaCl}, \mathrm{KCl}, \mathrm{MgCl}_{2}$ or $\mathrm{CaCl}_{2}$ were added to the filter paper dropwise. This amount of solution was completely absorbed in the filter paper. The resulting paper was dried over $\mathrm{P}_{2} \mathrm{O}_{5}$ in a vacuum desiccator for $24 \mathrm{~h}$ after air-drying at room temperature for $24 \mathrm{~h}$. The amount of the impregnation was $0.005,0.05,0.1,0.3$ and $0.5 \mathrm{~mol} / \mathrm{mol}$ of the glucose-unit of cellulose. Control sample were also prepared with pure water.

\subsection{Thermal analysis}

The impregnated cellulose samples were analyzed with thermogravimetric analysis (TGA) and differential thermal analysis (DTA) with Shimadzu TGA-50 [temperature program: room temperature to $750^{\circ} \mathrm{C}\left(10^{\circ} \mathrm{C} / \mathrm{min}\right)$ under $\mathrm{N}_{2}$-flow $(50 \mathrm{ml} / \mathrm{min})$ and isothermally at $750^{\circ} \mathrm{C}$ under air-flow (50 ml/min) for $30 \mathrm{~min}$ ] and Shimadzu DTA-50 [temperature program: room temperature to $750^{\circ} \mathrm{C}\left(10^{\circ} \mathrm{C} / \mathrm{min}\right)$ under $\mathrm{N}_{2}$ flow (50 $\mathrm{ml} / \mathrm{min}$ ) and isothermally at $750^{\circ} \mathrm{C}$ under air-flow (50 ml/min) for $30 \mathrm{~min}$ ], respectively.

\subsection{Isothermal pyrolysis of cellulose samples}

Isothermal pyrolysis of cellulose samples was conducted with the apparatus in Fig. 1. The control or impregnated samples were placed at the bottom of the reactor tube made of glass (inner diameter: $8 \mathrm{~mm}$, length: $300 \mathrm{~mm}$ ), and a nitrogen bag was attached to the reactor through tree-way tap and silicon rubber. After replacing the air inside the reactor with nitrogen using a vacuum pump, the reactor was inserted into a Muffle furnace (150, 200, 250, 300, 350 or $400^{\circ} \mathrm{C}$ ) through small hole and heated for $10 \mathrm{~min}$. After pyrolysis, the reactor was immediately cooled with flowing air for $1 \mathrm{~min}$ and opened. The residue (char or unreacted cellulose) was taken out from the bottom of the reactor and weighed. Then, the reactor and the residue were washed with $\mathrm{MeOH}$ 
$(2.0 \mathrm{ml})$ to give a $\mathrm{MeOH}$-soluble fraction.

\subsubsection{GPC analysis of the residue}

Degree of polymerization of cellulose in the residue was measured with gel permeation chromatography (GPC) after transformation into the phenyl carbamate derivative according to the literature [19]. Phenyl isocyanate $(0.33 \mathrm{ml})$ and pyridine $(1.0 \mathrm{ml})$ were added to the residue and vigorously stirred at $80^{\circ} \mathrm{C}$ for $24 \mathrm{~h}$. After the reaction, $\mathrm{MeOH}(2.0 \mathrm{ml})$ was added to the reaction mixture to quench the reaction, and then, the resulting solution was evaporated in vacuo and dried over $\mathrm{P}_{2} \mathrm{O}_{5}$ in a vacuum desiccator for $24 \mathrm{~h}$. The resulting mixture was redissolved in tetrahydrofuran (THF) and analyzed with GPC [Shimadzu LC-10A, column: Shodex KF803L + KF806, eluent: THF, flow rate: $0.6 \mathrm{ml} / \mathrm{min}$, detector: UV $254 \mathrm{~nm}$, column temperature: $40^{\circ} \mathrm{C}$ ]. The DP of cellulose in the residue was evaluated with polystyrene standards.

\subsubsection{XRD analysis of the residue}

The residue (sheet form) was directly attached to the sample holder without grinding, and X-ray diffraction (XRD) pattern of the residue was recorded with a Rigaku RINT 2000V (Cu K $\alpha, \lambda=1.542 \AA, 40$ kV, 30 mA).

\subsubsection{Low molecular weight products}

To evaluate the influence on the low molecular weight (MW) products from cellulose, isothermal pyrolysis was conducted under reduced pressure. Cellulose or impregnated cellulose samples were placed at the bottom of a round-shaped flask made of glass (30 ml volume). The flask was attached with a cooling tube (120 mm long and $14 \mathrm{~mm}$ in diameter). The cooling tube was further connected with an aspirator through a valve. Under reduced pressure (30 mmHg), the flask was soaked in a salt bath $\left(\mathrm{KNO}_{3} / \mathrm{NaNO}_{3}, 1: 1, \mathrm{w} / \mathrm{w}\right)\left(350^{\circ} \mathrm{C}\right)$ for $3 \mathrm{~min}$. After cooling the reaction system with flowing air (1 min), the whole glass ware and the residue were extracted with dimethyl sulfoxide (DMSO)- $d_{6}(1.0 \mathrm{ml})$ including $p$-dibromobenzene $(2.0 \mathrm{mg})$ as an internal standard. Extraction from the gas phase was not conducted, and hence some of the low MW products would be lost in this extraction.

The ${ }^{1} \mathrm{H}-\mathrm{NMR}$ spectrum of the DMSO- $d_{6}$ solution was recorded with a Brucker 
AC-400 spectrometer (400 MHz). The chemical shift was shown as $\delta$ value with tetramethylsilane (TMS) as an internal standard. Quantitative determination of the low MW products was conducted with the relative peak areas against the aromatic proton $(4 \mathrm{H})$ of $p$-dibromobenzene at $7.52 \mathrm{ppm}$. Characteristic well-resolved peaks were used for determination of furfural (aldehyde proton, $9.55 \mathrm{ppm}$ ), 5-hydroxymethyl furfural (5-HMF) (aldehyde proton, $9.53 \mathrm{ppm}$ ), glycolaldehyde (aldehyde proton, $9.60 \mathrm{ppm}$ ), hydroxyacetone (methyl proton, $2.02 \mathrm{ppm}$ ), acetic acid (methyl proton, $1.89 \mathrm{ppm}$ ), formic acid (aldehyde proton, $8.12 \mathrm{ppm}$ ), methanol (methyl proton, $3.15 \mathrm{ppm}$ ) and levoglucosan (C1 proton, $5.14 \mathrm{ppm}$ ).

Water formed from the isothermal pyrolysis of cellulose samples was determined with the MeOH-soluble fraction by using a Karl-Fischer moisture titrator MKC-520 (Kyoto Electronics MFG. Co. Ltd.).

\section{RESULTS AND DISCUSSION}

\subsection{Thermal analysis}

Figures 2 and 3 show the TG/DTG and DTA curves, respectively, measured for the cellulose samples impregnated with alkali metal chlorides $(\mathrm{NaCl}, \mathrm{KCl})$ and alkaline earth metal chlorides $\left(\mathrm{MgCl}_{2}, \mathrm{CaCl}_{2}\right)(0.50 \mathrm{~mol} / \mathrm{mol}$ of the glucose-unit of cellulose $)$. In Fig. 2, weight of the untreated cellulose rapidly decreases around $350^{\circ} \mathrm{C}$ up to the residue yield less than $10 \%$. Contrary to this, all impregnated samples show 2-stage weight loss at $<400^{\circ} \mathrm{C}$ and $>500^{\circ} \mathrm{C}$. Consequently, this leads to leaving substantial amount of residue (30-50\%) at the temperature range between $400-500^{\circ} \mathrm{C}$. Some exothermic peaks that are newly observed at $>500^{\circ} \mathrm{C}$ in their DTA curves (Fig.3) would correspond to this higher temperature weight loss.

$\mathrm{MgCl}_{2}$ and $\mathrm{CaCl}_{2}$ are known to have hydrated water, and complete removal of this water was difficult even at temperatures higher than the boiling point of water. Figure 4 shows the TG curves of the neat alkali and alkaline earth metal chlorides obtained by drying their aqueous solutions under the similar drying conditions (air drying /r.t. / 24h followed by $\mathrm{P}_{2} \mathrm{O}_{5} /$ vacuum desiccator / 24h). $\mathrm{NaCl}$ and $\mathrm{KCl}$ were completely dehydrated under these drying conditions, while the $\mathrm{MgCl}_{2}$ and $\mathrm{CaCl}_{2}$ samples lost their weight around $100-200^{\circ} \mathrm{C}$ and $200-300^{\circ} \mathrm{C}$, respectively. In the TG curve of $\mathrm{MgCl}_{2}$, 
further weight loss was observed even above $500^{\circ} \mathrm{C}$. According to the literature (equation 1) [20, 21], this weight loss behavior corresponds to the dehydration of the hydrated $\mathrm{MgCl}_{2}$. High temperature dehydration is explained with the strong hydration ability of $\mathrm{Mg}^{2+}$ [20]. Such water should not be ignored in the TG/DTG analysis of the alkaline earth metal chloride-impregnated cellulose. Supposing the dehydration of $\mathrm{MgCl}_{2}$ and $\mathrm{CaCl}_{2}$ proceeds similarly in the impregnated samples, the amounts of water from such dehydration are estimated as 2.5 and $4.0 \%$, respectively, at the maximum loading of $0.5 \mathrm{~mol} / \mathrm{mol}$ of the glucose-unit. So, influence of this dehydration on the TG curves of the $\mathrm{MgCl}_{2}$ - and $\mathrm{CaCl}_{2}$-impregnated samples is expected be comparatively small under the levels of addition in this paper.

$\mathrm{MgCl}_{2} \cdot 6 \mathrm{H}_{2} \mathrm{O} \stackrel{117-160^{\circ} \mathrm{C}}{\longrightarrow} \mathrm{MgCl}_{2} \cdot 4 \mathrm{H}_{2} \mathrm{O} \stackrel{190^{\circ} \mathrm{C}}{\longrightarrow} \mathrm{MgCl}_{2} \cdot 2 \mathrm{H}_{2} \mathrm{O}$

Equation (1)

$\stackrel{240^{\circ} \mathrm{C}}{\longrightarrow} \mathrm{MgCl}_{2} \cdot \mathrm{H}_{2} \mathrm{O} \stackrel{285^{\circ} \mathrm{C}}{\longrightarrow} \mathrm{Mg}(\mathrm{OH}) \mathrm{Cl}+\mathrm{HCl} \stackrel{520^{\circ} \mathrm{C}}{\longrightarrow} \mathrm{MgCl}_{2}+\mathrm{MgO}$

Alkali and alkaline earth metal chlorides showed different weight loss behaviors bellow $400^{\circ} \mathrm{C}$. Although $\mathrm{NaCl}$ and $\mathrm{KCl}$ lowered the weight loss-starting temperature slightly, the large DTG peak at $350^{\circ} \mathrm{C}$ (Fig. 2), which corresponds to the bulk cellulose pyrolysis, was not altered with these salts. Thus, the influence of alkali metal chlorides on bulk cellulose pyrolysis is comparatively small. This is also supported by their DTA results (Fig. 3). The exothermic peak around $350^{\circ} \mathrm{C}$ (untreated cellulose), which would arise from the bulk cellulose carbonization, was similarly observed in the alkali metal-impregnated samples. The endothermic peak around $330^{\circ} \mathrm{C}$ observed for the untreated cellulose disappeared in the alkali metal-impregnated samples. These results would relate to the change in the volatile product composition as discussed later.

On the other hand, $\mathrm{MgCl}_{2}$ and $\mathrm{CaCl}_{2}$ substantially lowered the weight loss-temperature of bulk cellulose. Consequently, the DTG peak at $350^{\circ} \mathrm{C}$ (untreated cellulose) shifted to much lower temperatures of $210^{\circ} \mathrm{C}\left(\mathrm{MgCl}_{2}\right)$ and 250 and $300^{\circ} \mathrm{C}$ $\left(\mathrm{CaCl}_{2}\right)$ (Fig. 2). Concurrently, both exothermic and endothermic peaks around $300-400^{\circ} \mathrm{C}$ disappeared in the DTA curves of the alkaline earth metal impregnated samples (Fig. 3). 
The influences of the amount of loading on the TG curve are shown in Fig. 5. The weight loss behaviors (bellow $400^{\circ} \mathrm{C}$ ) of the $\mathrm{NaCl}$ - and $\mathrm{KCl}$-impregnated samples were almost independent of the amount of loading, while the TG curves of the $\mathrm{MgCl}_{2}$ - and $\mathrm{CaCl}_{2}$-impregnated samples drastically changed depending on the level of addition bellow $0.30 \mathrm{~mol} / \mathrm{mol}$ of the glucose-unit. At this level, their influences were saturated. Such strong influence of the amount would be a reason why conflicting results are reported for the influence of alkaline earth metal halide $[5,11,16,17]$. Some literature $[11,15]$ reported that the influences of $\mathrm{MgCl}_{2}$ and $\mathrm{CaCl}_{2}$ on cellulose pyrolysis were very small, although their strong influences are reported in other papers $[16,17]$.

\subsection{Isothermal pyrolysis}

The untreated or impregnated cellulose samples ( $0.50 \mathrm{~mol} / \mathrm{mol}$ of the glucose-unit) were pyrolyzed isothermally at the temperature between $150-400^{\circ} \mathrm{C}$ in atmospheric $\mathrm{N}_{2}$ for $10 \mathrm{~min}$. Changes in the residue yields are shown in Fig. 6. As indicated from the TG/DTA results (Fig. 2), the weight loss-starting temperature $\left(300^{\circ} \mathrm{C}\right)$ of cellulose was lowered in the impregnated samples in the order of $\mathrm{MgCl}_{2}<\mathrm{CaCl}_{2}<\mathrm{KCl}, \mathrm{NaCl}<$ untreated. Especially, the influences of the alkaline earth metal chlorides were significant, and the weight loss of the impregnated samples was almost completed at $200-250^{\circ} \mathrm{C}\left(\mathrm{MgCl}_{2}\right)$ and $250-300^{\circ} \mathrm{C}\left(\mathrm{CaCl}_{2}\right)$.

Reduction of the pyrolysis temperature is also shown by the changes in the XRD pattern of the residue (Fig. 7) and the water yield determined with the Carl-Fishcher moisture titration of the MeOH-soluble fractions (Fig. 8). As shown in Fig. 7, the cellulose I-type XRD pattern [2 $\theta: 14.4^{\circ}(101), 16.0^{\circ}(101), 22.8^{\circ}(002)$ ] [22] became smaller and finally disappeared with increasing the pyrolysis temperature. Alkaline earth metal chlorides $\left(\mathrm{MgCl}_{2}\right.$ and $\left.\mathrm{CaCl}_{2}\right)$ lowered this disappearing temperature from $350^{\circ} \mathrm{C}$ (untreated cellulose) to 250 and $300^{\circ} \mathrm{C}$, respectively. Alkali metal chloride did not change the temperature. These results also support the earlier conclusion from the TG/DTG analysis (Fig. 2) that alkaline earth metal chloride accelerates the bulk cellulose pyrolysis.

In pyrolysis of the cellulose samples, large amount of water was formed from 
dehydration and carbonization reactions (Fig. 8). Water started to form at $300^{\circ} \mathrm{C}$ from the untreated cellulose and the yield increased substantially at $350^{\circ} \mathrm{C}$. Influence of $\mathrm{NaCl}$ and $\mathrm{KCl}$ on this water formation temperature was comparatively small, whereas the maximum yields of water from the alkaline earth metal chlorides-impregnated samples were obtained at much lower temperatures of $200\left(\mathrm{MgCl}_{2}\right)$ and $250^{\circ} \mathrm{C}\left(\mathrm{CaCl}_{2}\right)$. These results also indicate that carbonization of the alkaline earth metal chloride-impregnated samples occurs at temperatures as low as $200^{\circ} \mathrm{C}$.

Figure 9 shows the change in the DP of cellulose in the residue as a function of the pyrolysis temperature. The phenyl carbamate derivatives were not obtained from the residues of the impregnated samples $\left(>250^{\circ} \mathrm{C}\right)$ and the untreated cellulose $\left(350^{\circ} \mathrm{C}\right)$, probably due to their poor accessibility to the reagents in the composite structure with the carbonized products. The DP of the untreated cellulose decreased with increasing the pyrolysis temperature and leveled off around 300 (polystyrene standard), which corresponds to the level-off DP described by many papers in acid hydrolysis [23, 24] and pyrolysis conditions [25-27]. The salts, especially alkaline earth metal chlorides, accelerated their DP reduction.

As for the low MW products, ${ }^{1} \mathrm{H}-\mathrm{NMR}$ analysis was used for the measurement of the $\mathrm{MeOH}$-soluble fractions, including levoglucosan, 5-hydroxymethyl furfural (5-HMF), furfural, hydroxyacetone, formic acid, acetic acid and methanol. The yields were quite low due to secondary reactions. In order to prevent these secondary reactions, isothermal pyrolysis $\left(350^{\circ} \mathrm{C}\right)$ under reduced pressure $(30 \mathrm{mmHg})$ was conducted at $0.005,0.05$ and $0.5 \mathrm{~mol} / \mathrm{mol}$ of the glucose-unit. The influences of the impregnation on the low MW products formation are summarized in Fig. 10. The yields of levoglucosan, 5-HMF and methanol substantially decreased in the presence of these salts. The other products tend to increase in their yields at the low level of addition and decrease at the high level of addition. These influences were not so different between alkali and alkaline earth metal chlorides except for levoglucosan at the lowest level of addition.

Levoglucosan is the important primary pyrolysis product of pure cellulose, and it is well documented that inorganic matter reduces this yield $[6,7,9,13]$. Levoglucosan yields from the alkali metal chloride-impregnated samples were quite low even at the lowest level of $0.005 \mathrm{~mol} / \mathrm{mol}$ of the glucose-unit, and the yield slightly increases with 
increasing the level of addition. Contrary to this, comparatively small influences of alkaline earth metal chlorides were observed at the lowest level of addition [e.g. $\mathrm{MgCl}_{2}$ -impregnated sample: levoglucosan yield: 15.4\%].

\subsection{Different action of alkali / alkaline earth metal chlorides}

The influences of alkali and alkaline earth metal chlorides observed in this study are summarized in Table 1. The composition of the low MW products was altered significantly with both types of the metal chlorides. On the other hand, the influences on the pyrolysis temperature of bulk cellulose were quite different between these two metal types. Consequently, these two kinds of influences would arise from the different mechanisms. Further study is necessary to identify the mechanism, but the influences on the low MW product composition would relate to some radical chain reaction induced by these metal chlorides, since even a very low level of addition was quite effective.

As for the reduction mechanism of the pyrolysis temperature of bulk cellulose, the alkaline earth metal chlorides would change the reactivity of the surface molecules in crystalline cellulose, due to the difficulty in migration of the salts into the crystalline structure. Kawamoto et al. [28, 29] reported that cellulose pyrolysis starts from the surface molecules because the inner molecules are stabilized through extensive intra and intermolecular interactions. Shimada et al. [30] have reported that the hydrated $\mathrm{MgCl}_{2}$ promoted the solid-state hydrolysis of methyl $\alpha / \beta$-glucosides even at the temperature higher than the boiling point of water, with the catalytic activity of $\mathrm{Mg}^{2+}$ as a Lewis acid and the hydrated water as a nucleophile. The activation of the surface cellulose molecule by alkaline earth metal chlorides would relate to this solid-state hydrolysis. It has been reported that carbohydrate pyrolysis starts with cleavage of the glycosidic bond [31, 32].

\section{COCLUSIONS}

Influences of alkali and alkaline earth metal chlorides on cellulose pyrolysis were studied with thermal analysis and isothermal pyrolysis. Both types significantly changed the low MW product composition even at a very low level of addition, while the influences on the bulk cellulose pyrolysis were different between alkali and alkaline 
earth metal chlorides. Alkaline earth metal chlorides extremely lowered the bulk cellulose pyrolysis temperature, and this was strongly dependent on the loading bellow $0.30 \mathrm{~mol} / \mathrm{mol}$ of the glucose-unit.

\section{ACKNOWLEDGEMENT}

This work was supported by 21st COE program "Establishment of COE on Sustainable-Energy System” (2002. 4 - 2007. 3) supported by the Ministry of Education, Culture, Sports, Science and Technology, Japan.

\section{REFERENCES}

[1] W.F. DeGroot, F. Shafizadeh, J. Anal. Appl. Pyrolysis 6 (1984) 217.

[2] W. Pan, G.N. Richards, J. Anal. Appl. Pyrolysis 16 (1989) 117.

[3] J. Piskorz, D.St.A.G. Radlein, D.S. Scott, S. Czernik, J. Anal. Appl. Pyrolysis 16 (1989) 127.

[4] A. Jensen, K. Dam-Johansen, Energy Fuels 12 (1998) 929.

[5] M. Müller-Hagedorn, H. Bockhorn, L. Krebs, U. Müller, J. Anal. Appl. Pyrolsis 68-69 (2003) 231.

[6] F. Shafizadeh, R.H. Furneaux, T.G. Cochran, J.P. Scholl, Y. Sakai, J. Appl. Polymer. Sci. 23 (1979) 3525.

[7] T. Hosoya, H. Kawamoto, S. Saka, J. Wood Sci. 53 (2007) 351.

[8] G.N. Richards, G. Zheng, J. Anal. Appl. Pyrolysis 21 (1991) 133.

[9] Y. Tsuchiya, K. Sumi, J. Appl. Polymer Sci. 14 (1970) 2003.

[10] D.P.C Fung, Y. Tsuchiya, K. Sumi, Wood Sci. 5 (1972) 38.

[11] G. Várhegyi., M.J. Antal, Jr., T. Szekely, E. Jakab, Energy Fuels 2 (1988) 267.

[12] F. Shafizadeh, Y. Sekiguchi Development of aromaticity in cellulosic chars. Carbon 21(5) (1983) 511.

[13] Y. Halpern, S. Patai, Isr. J. Chem. 7 (1969) 685.

[14] B.K. Kandola, A.R. Horrocks, D. Price, G.V. Coleman, J. M. S.-Rev. Macromol. Chem. Phys. C36 (4) (1996) 721.

[15] S.L. Madorsky, V.E. Hart, S. Straus, J. Res. Natn. Bur. Stand. 56(6) (1956) 343.

[16] H. Kawamoto, D. Yamamoto, S. Saka, J. Wood Sci., in press.

[17] Data from Advantec Toyo Kaisha, Ltd. 
[18] T.E. McGrath, J.A. Hoffman, J.B. Wooten, M.R. Hajaligol, Prep. Symp. - Am. Chem. Soc. Div. Fuel Chem. 47(1) (2002) 418.

[19] A. Isogai, M. Usuda, Mokuzai Gakkaishi 37(4) (1991) 339.

[20] J.C.J. Bart, W. Roovers, J. Mater. Sci. 30 (1995) 2809.

[21] G. Wehner, Z. Anorg. Allg. Chem. 272 (1953) 201.

[22] L. Segal, J.J. Greely, A.E. Martin, Jr., C.M. Conrad, Textile Res. J. 29 (1959) 786.

[23] O.A. Battista, S. Coppick, Textile Res. J. 17 (1947) 419.

[24] P.C. Mehta, E. Pacsu, Textile Res. J. 18 (1948) 387.

[25] O.P. Golova, R.G. Krylova, Dokl. Akad. Nauk., SSSR 116 (1957) 419.

[26] Y. Halpern, S. Patai, Isr. J. Chem. 7 (1969) 673.

[27] A. Broido, A.C. Javier-Son, A.C. Ouano, E.M. Barral, J. Appl. Polym. Sci. 17 (1973) 3627.

[28] H. Kawamoto, W. Hatanaka, S. Saka, J. Anal. Appl. Pyrolysis 70 (2003) 303.

[29] H. Kawamoto, S. Saka, J. Anal. Appl. Pyrolysis 76 (2006) 280.

[30] N. Shimada, H. Kawamoto, S. Saka, Carbohydrate Res. 342 (2007) 1373..

[31] F. Shafizadeh, J. Polym. Sci., Part C (1971) 21.

[32] F. Shafizadeh, Appl. Polym. Symp. (1975) 153. 


\section{Legend of Figures and Table}

Fig. 1. Experimental set-up for isothermal pyrolysis.

Fig. 2. TG and DTG curves of the impregnated cellulose samples $(0.50 \mathrm{~mol} / \mathrm{mol}$ of the glucose-unit) (in $\mathrm{N}_{2} / 10^{\circ} \mathrm{C} / \mathrm{min}$ ).

Fig. 3. DTA curves of the impregnated cellulose samples $(0.50 \mathrm{~mol} / \mathrm{mol}$ of the glucose-unit) (in $\mathrm{N}_{2} / 10^{\circ} \mathrm{C} / \mathrm{min}$ ).

Fig. 4. TG curves of the neat alkali and alkaline earth metal chlorides (in $\mathrm{N}_{2} / 10^{\circ} \mathrm{C} /$ $\min )$.

Fig. 5. Influence of the amount of loading on the TG curve of cellulose (in $\mathrm{N}_{2} / 10^{\circ} \mathrm{C} /$ $\min )$.

- - - : : untreated, ……..... : 0.005, …......... : 0.050, -. - : 0.100,

$-\cdots-: 0.300, \quad \longrightarrow: 0.500 \mathrm{~mol} / \mathrm{mol}$ of the glucose-unit.

Fig. 6. Change in the residue yield in isothermal pyrolysis of the impregnated cellulose samples( $0.50 \mathrm{~mol} / \mathrm{mol}$ of the glucose-unit) (in $\left.\mathrm{N}_{2} / 350^{\circ} \mathrm{C} / 10 \mathrm{~min}\right)$.

Fig. 7. Change in the XRD pattern of the residue in isothermal pyrolysis of the impregnated cellulose samples $\left(0.50 \mathrm{~mol} / \mathrm{mol}\right.$ of the glucose-unit) (in $\mathrm{N}_{2}$ / $\left.350^{\circ} \mathrm{C} / 10 \mathrm{~min}\right)$.

Fig. 8. Yields of water in isothermal pyrolysis of the impregnated cellulose samples ( $0.50 \mathrm{~mol} / \mathrm{mol}$ of the glucose-unit) (in $\left.\mathrm{N}_{2} / 350^{\circ} \mathrm{C} / 10 \mathrm{~min}\right)$.

Fig. 9. Change in the DP of the residue in isothermal pyrolysis of the impregnated cellulose samples $\left(0.50 \mathrm{~mol} / \mathrm{mol}\right.$ of the glucose-unit) (in $\mathrm{N}_{2} / 350^{\circ} \mathrm{C} / 10$ $\min )$.

$\square$ : untreated, $\bigcirc: \mathrm{NaCl}, \triangle: \mathrm{KCl}, \mathrm{O}: \mathrm{MgCl}_{2}, \boldsymbol{\Delta}: \mathrm{CaCl}_{2}$. 
Fig. 10. Influence of the amount of loading on the yields of some low MW products in isothermal pyrolysis of the impregnated cellulose samples $(0.50 \mathrm{~mol} / \mathrm{mol}$ of the glucose-unit) (in $\mathrm{N}_{2} / 30 \mathrm{mmHg} / 350^{\circ} \mathrm{C} / 10 \mathrm{~min}$ ).

$\square$ : untreated, $\bigcirc: \mathrm{NaCl}, \triangle: \mathrm{KCl}, \mathrm{O}: \mathrm{MgCl}_{2}, \boldsymbol{\Delta}: \mathrm{CaCl}_{2}$.

Table 1. Summary of the influences of alkali and alkaline earth metal chlorides on cellulose pyrolysis. 


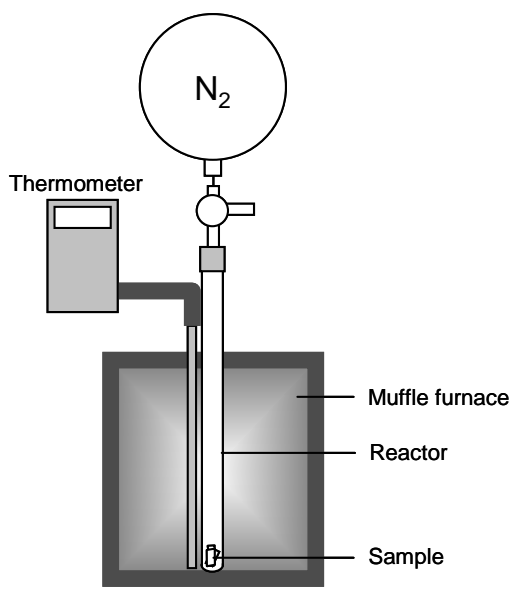

Fig. 1. Experimental set-up for isothermal pyrolysis. 

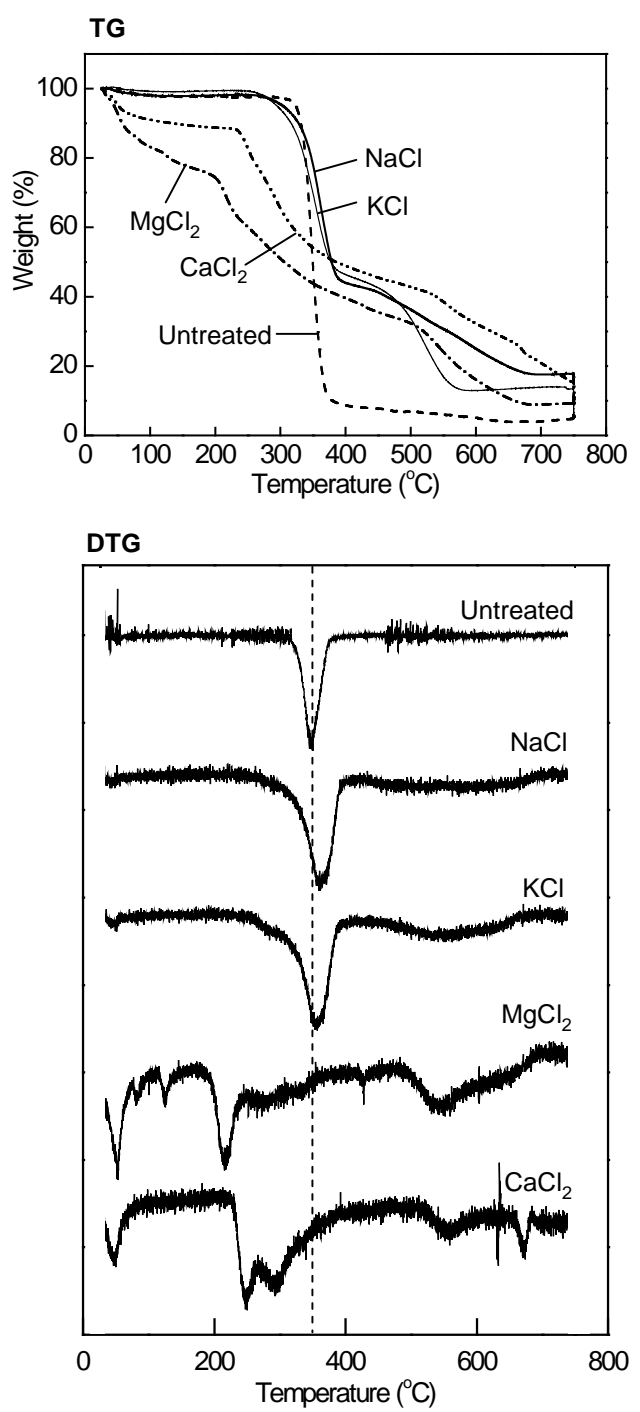

Fig. 2. TG and DTG curves of the impregnated cellulose samples $(0.50 \mathrm{~mol} / \mathrm{mol}$ of the glucose-unit) (in $\mathrm{N}_{2} / 10^{\circ} \mathrm{C} / \mathrm{min}$ ). 


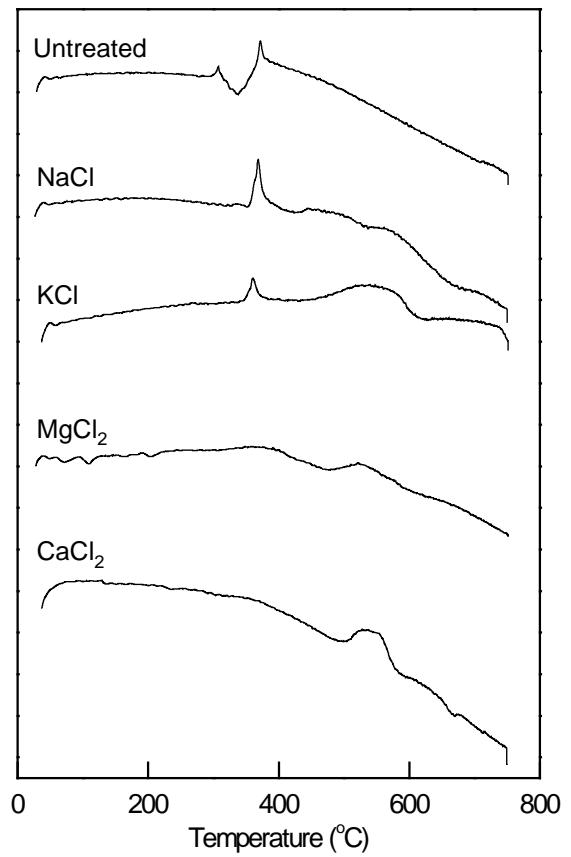

Fig. 3. DTA curves of the impregnated cellulose samples $(0.50 \mathrm{~mol} / \mathrm{mol}$ of the glucose-unit) (in $\mathrm{N}_{2} / 10^{\circ} \mathrm{C} / \mathrm{min}$ ). 


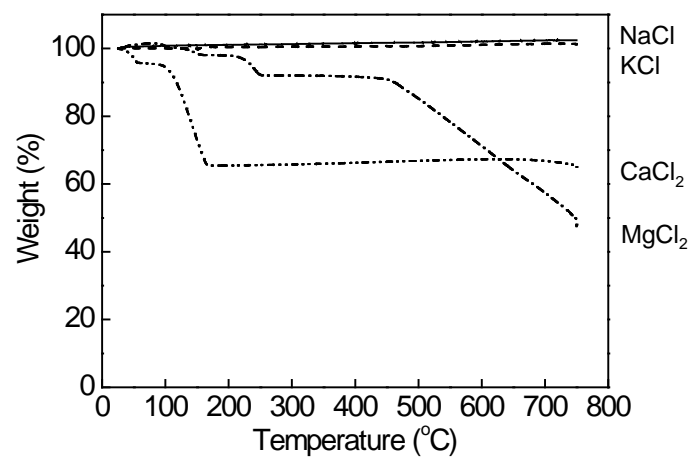

Fig. 4. TG curves of the neat alkali and alkaline earth metal chlorides (in $\mathrm{N}_{2} / 10^{\circ} \mathrm{C} /$ $\min )$. 

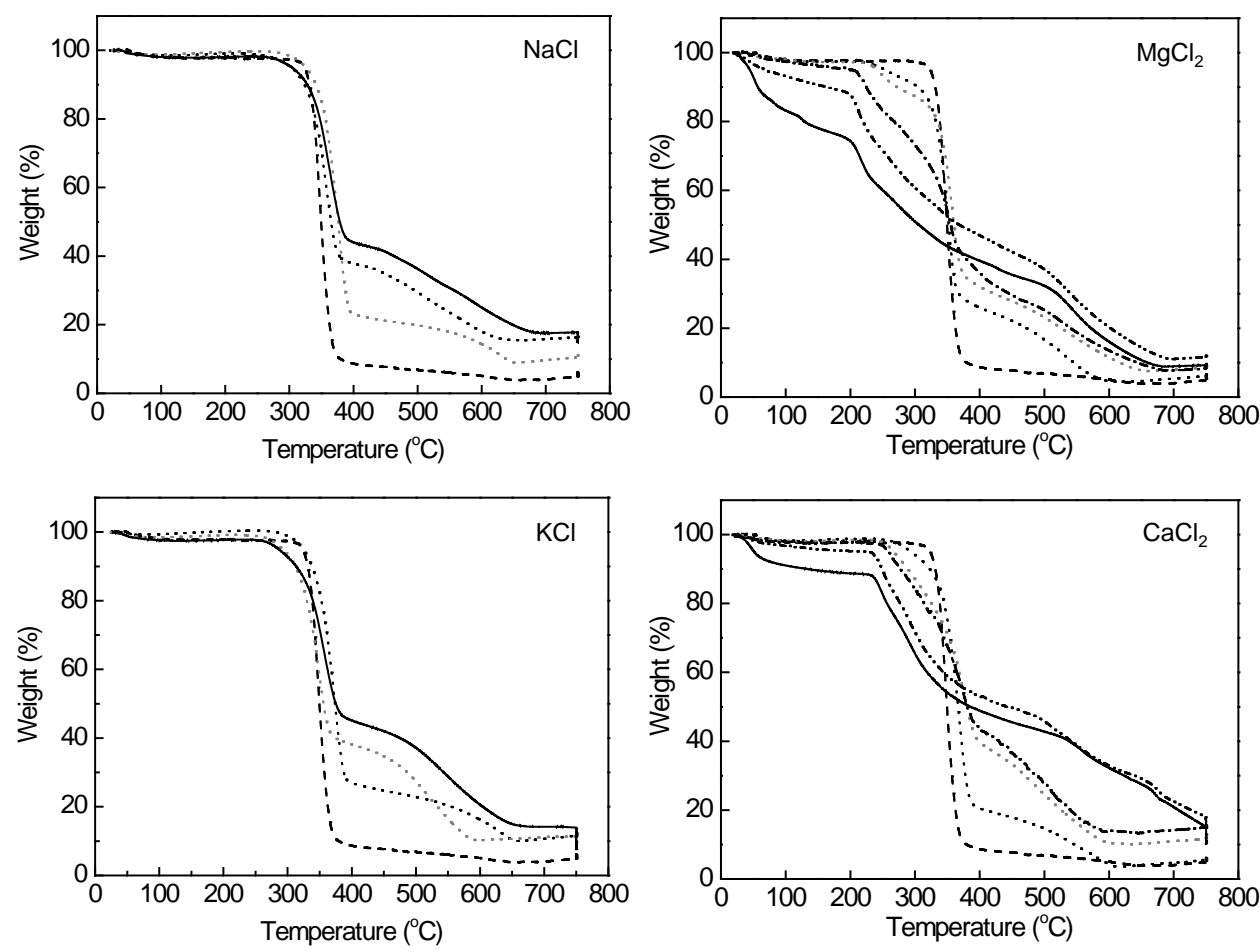

Fig. 5. Influence of the amount of loading on the TG curve of cellulose (in $\mathrm{N}_{2} / 10^{\circ} \mathrm{C} /$ $\min )$.

- - - - : untreated, :0.005, $: 0.050,-\cdot-: 0.100$

$-\cdots-$ : 0.300, : $0.500 \mathrm{~mol} / \mathrm{mol}$ of the glucose-unit. 

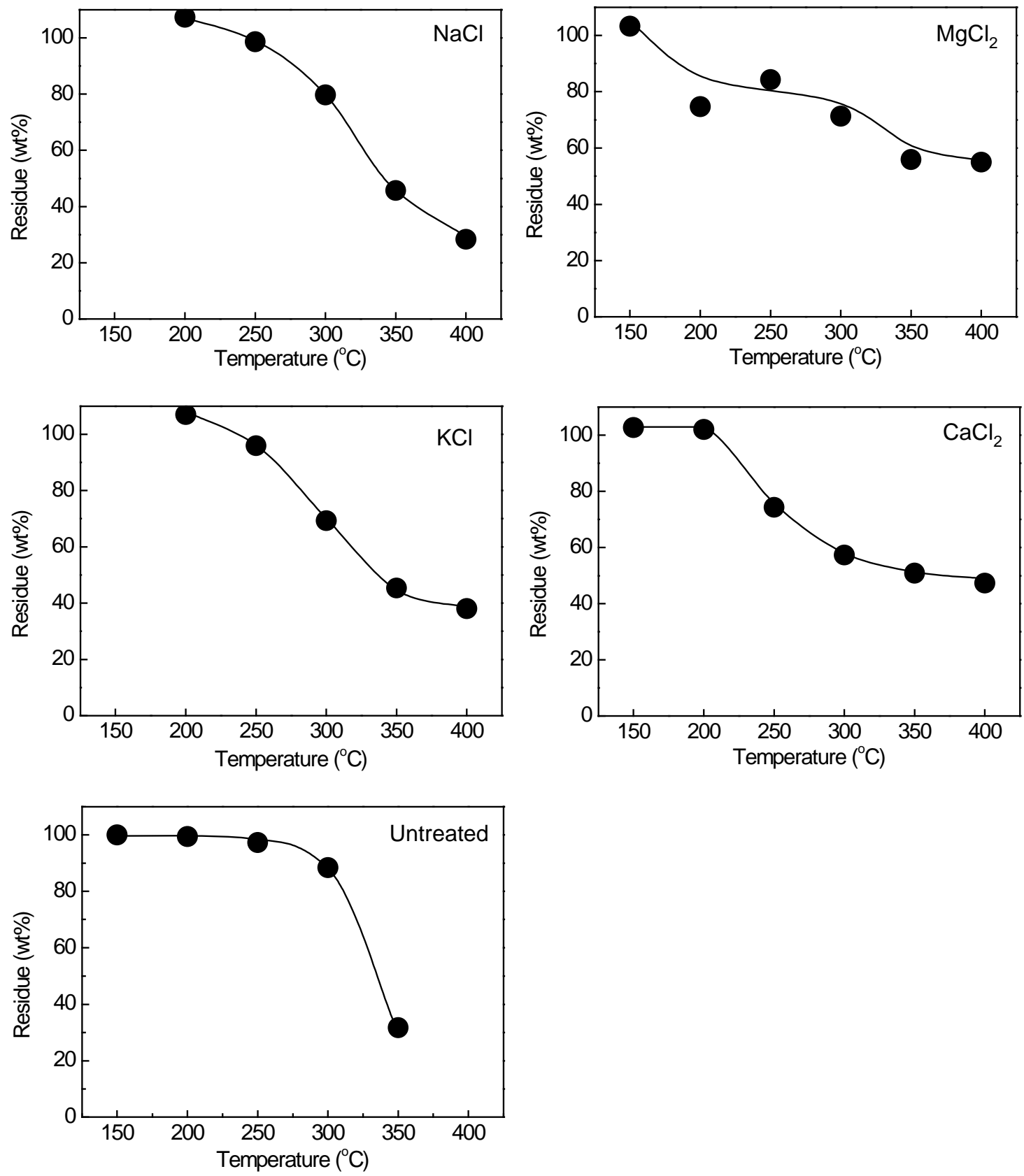

Fig. 6. Change in the residue yield in isothermal pyrolysis of the impregnated cellulose samples $\left(0.50 \mathrm{~mol} / \mathrm{mol}\right.$ of the glucose-unit) (in $\left.\mathrm{N}_{2} / 350^{\circ} \mathrm{C} / 10 \mathrm{~min}\right)$. 


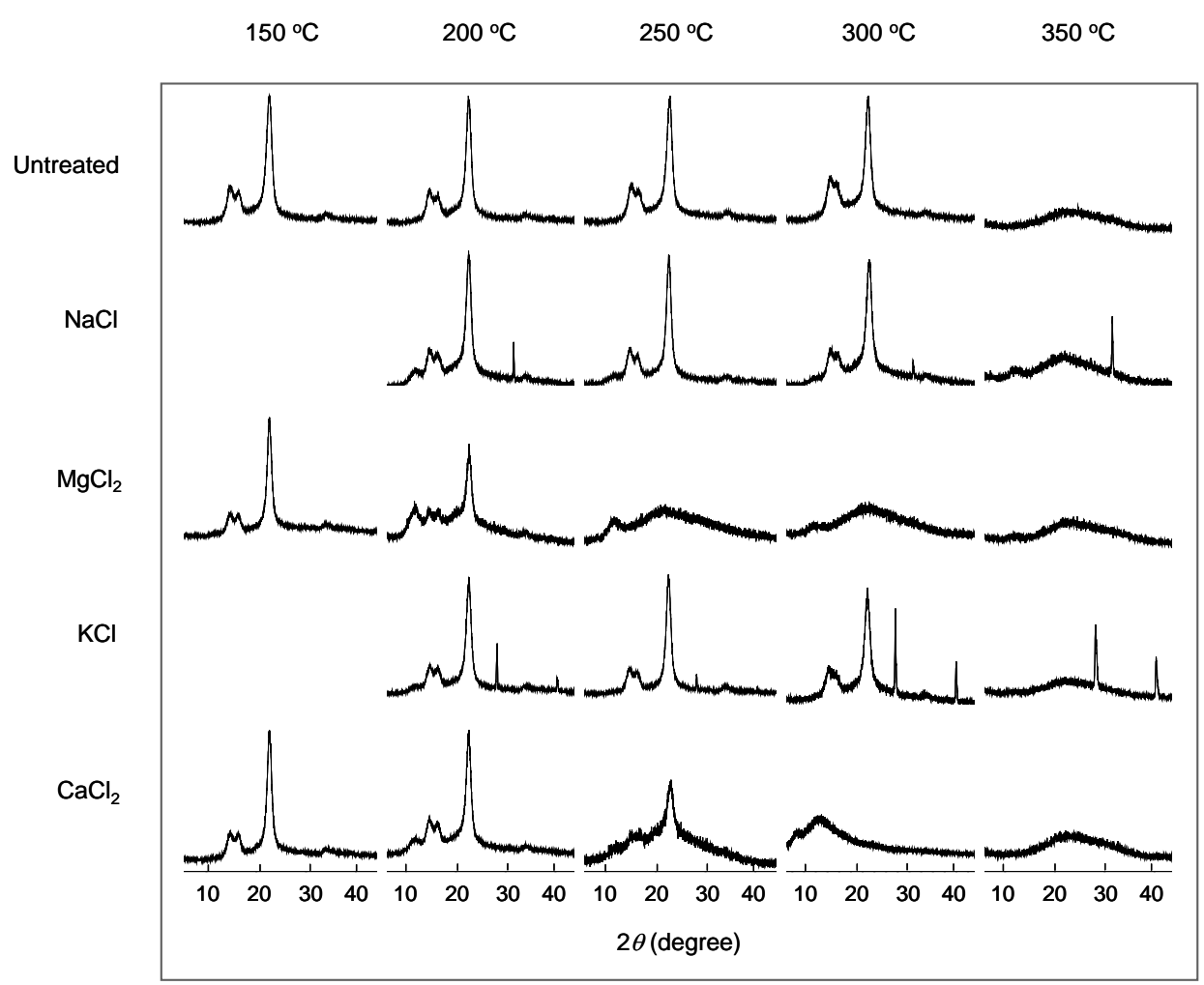

Fig. 7. Change in the XRD pattern of the residue in isothermal pyrolysis of the impregnated cellulose samples ( $0.50 \mathrm{~mol} / \mathrm{mol}$ of the glucose-unit) (in $\mathrm{N}_{2}$ / $\left.350^{\circ} \mathrm{C} / 10 \mathrm{~min}\right)$. 


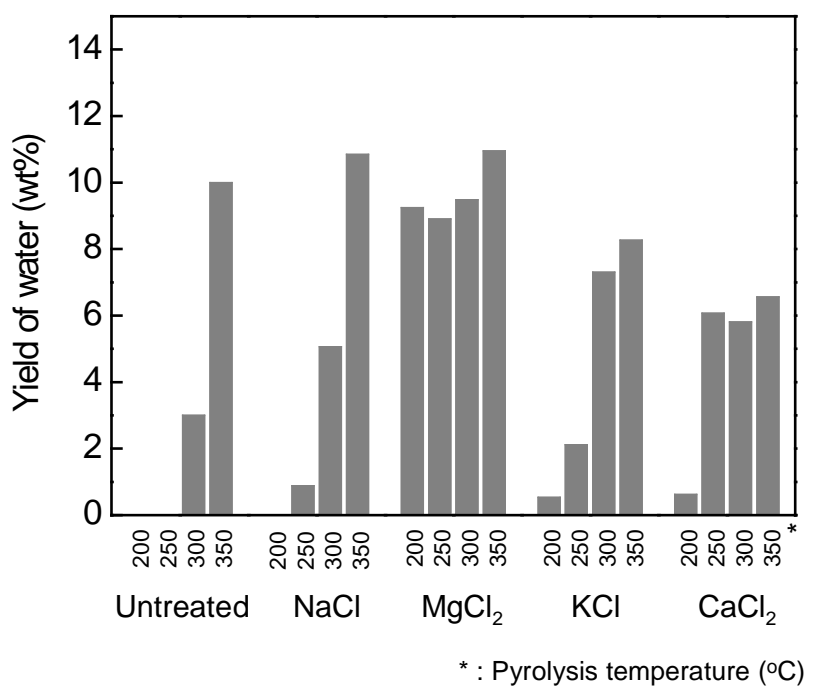

Fig. 8. Yields of water in isothermal pyrolysis of the impregnated cellulose samples (0.50 mol / mol of the glucose-unit) (in $\mathrm{N}_{2} / 350^{\circ} \mathrm{C} / 10 \mathrm{~min}$ ). 


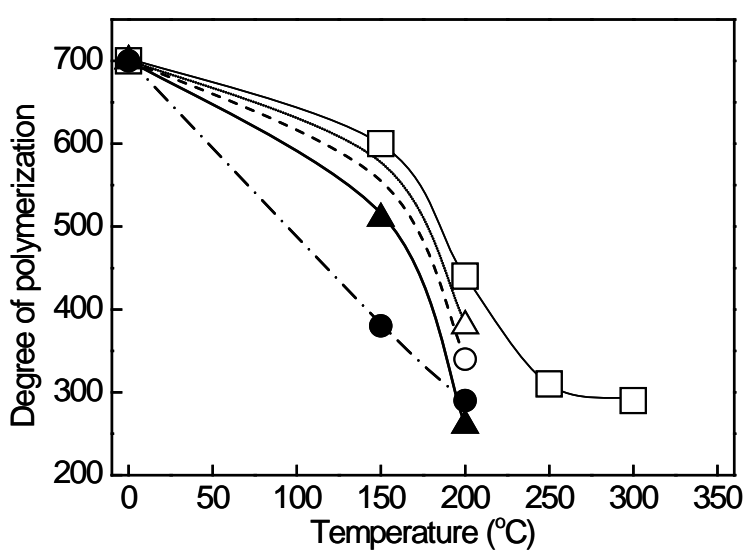

Fig. 9. Change in the DP of the residue in isothermal pyrolysis of the impregnated cellulose samples $\left(0.50 \mathrm{~mol} / \mathrm{mol}\right.$ of the glucose-unit) (in $\mathrm{N}_{2} / 350^{\circ} \mathrm{C} / 10$ $\min )$.

$\square$ : untreated, $\bigcirc: \mathrm{NaCl}, \triangle: \mathrm{KCl}, \mathbf{O}: \mathrm{MgCl}_{2}, \boldsymbol{\Delta}: \mathrm{CaCl}_{2}$. 

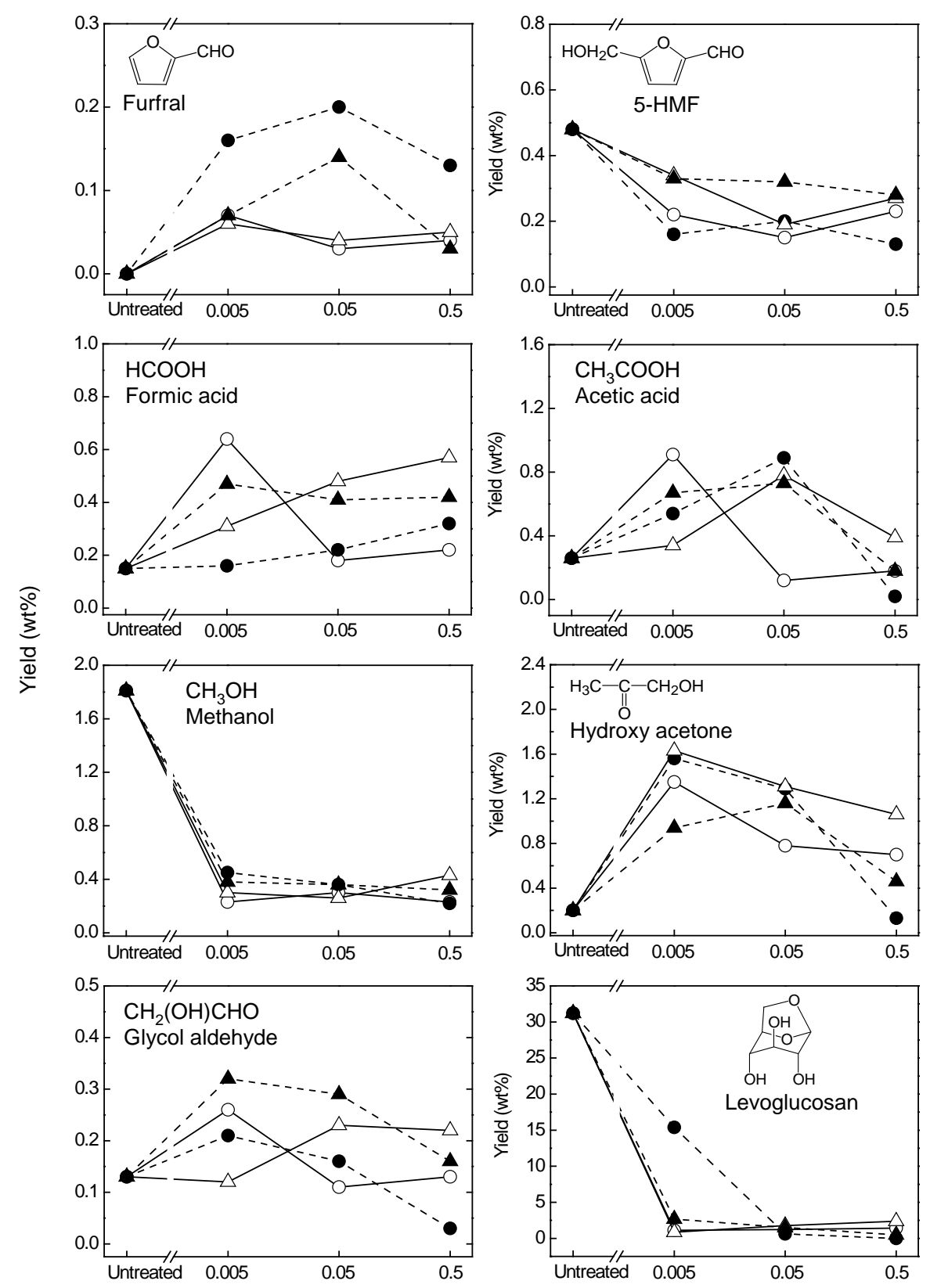

Mole of chloride / mole of the glucose-unit in cellulose

Fig. 10. Influence of the amount of loading on the yields of some low MW products in isothermal pyrolysis of the impregnated cellulose samples $(0.50 \mathrm{~mol} / \mathrm{mol}$ of the glucose-unit) (in $\mathrm{N}_{2} / 30 \mathrm{mmHg} / 350^{\circ} \mathrm{C} / 10 \mathrm{~min}$ ).

$\square$ : untreated, $\bigcirc: \mathrm{NaCl}, \triangle: \mathrm{KCl}, \mathrm{O}: \mathrm{MgCl}_{2}, \boldsymbol{\Delta}: \mathrm{CaCl}_{2}$. 
Table 1. Summary of the influences of alkali and alkaline earth metal chlorides on cellulose pyrolysis.

\begin{tabular}{lccc}
\hline & $\begin{array}{l}\text { Reduction of the } \\
\text { pyrolysis temperature } \\
\text { of bulk cellulose }\end{array}$ & $\begin{array}{l}\text { Influence of } \\
\text { the amount } \\
\text { of loading }\end{array}$ & $\begin{array}{l}\text { Influence on } \\
\text { the low MW } \\
\text { products }\end{array}$ \\
\hline $\begin{array}{l}\text { Alkali metal } \\
\text { chloride }\end{array}$ & Small & Small & Large \\
$\begin{array}{l}\text { Alkaline earth } \\
\text { metal chloride }\end{array}$ & Large & Large & Large \\
& {$\left[\begin{array}{c}<0.30 \text { mol / mol } \\
\text { of the glucose-unit }\end{array}\right]$} & \\
\hline
\end{tabular}

